\title{
Cholesterol and Malondialdehyde Contents of Broiler-Chicken Meat Supplemented with Indigofera zolingeriana Top Leaf Meal
}

\author{
M. A. Santia ${ }^{a}$ Sumiati $^{\mathrm{b}, *}$, \& L. Abdullah ${ }^{\mathrm{b}}$ \\ aStudy Program of Nutrition and Feed Science, Faculty of Animal Science, Graduate School, \\ Bogor Agricultural University \\ ${ }^{b}$ Department of Nutrition and Feed Technology, Faculty of Animal Science, Bogor Agricultural University \\ Jalan Agatis, Kampus IPB Darmaga Bogor 16680, Indonesia \\ (Received 13-05-2015; Reviewed 08-06-2015; Accepted 31-08-2015)
}

\begin{abstract}
This research aimed to increase functional value of broiler-chicken meat containing high antioxidant and low cholesterol through substitution of soybean meal (SBM) with Indigofera zollingeriana top leaf meal (ILM). The experiment used 160 day old broiler chicken (Cobb strain). The experimental chicken were provided dietary treatments when they were 15-days old (initial body weight of $460.5 \pm 1.56 \mathrm{~g} / \mathrm{bird}$ ) and terminated on day 35 . A completely randomized design (CRD) with four treatments and four replications and ten birds in each replication was used in this experiment. Dietary treatments were: $\mathrm{R} 1=$ diet containing $20 \%$ soybean meal $(\mathrm{SBM})$ without $I$. zollingeriana top leaf meal (ILM); R2= diet containing 16\% SBM and 5.9\% ILM; R3= diet containing 12\% SBM and 11.8\% ILM; R4= diet containing $8 \%$ SBM and $\mathbf{1 7 . 7 4 \%}$ ILM. Variables measured were performances (feed consumption, body weight gain, and feed conversion) and the quality of broiler meat (cholesterol, fat content, and malondialdehyde [MDA] concentration). The results showed that supplementation of $17.74 \%$ ILM (R4) as the substitution of $60 \%$ soybean meal protein produced the same performances of broilers as those of control diet (R1). Supplementation of $11.8 \%$ ILM as the substitution of $40 \%$ soybean meal protein (R3) decreased meat cholesterol by $34.70 \%$, meat fat content by $52.93 \%$, and MDA concentration by $62.52 \%$. The conclusion of this study was that supplementation of $17.74 \%$ ILM produced the same performances as that of control diet, increased antioxidant content of the meat, indicated by a lower MDA concentration, and decreased cholesterol, as well as fat content of broiler-chicken meat.
\end{abstract}

Key words: broiler performance, cholesterol, Indigofera zollingeriana, malondialdehyde (MDA)

\section{ABSTRAK}

Penelitian ini bertujuan untuk meningkatkan nilai fungsional daging ayam broiler yang tinggi antioksidan dan rendah kolesterol melalui substitusi bungkil kedelai dengan tepung pucuk Indigofera (Indigofera zollingeriana). Penelitian menggunakan 160 ekor DOC broiler strain Cobb, yang diberi ransum perlakuan mulai umur 15 hari (bobot badan awal 460 $\pm 1,56$ g/ekor) sampai umur 35 hari. Penelitian menggunakan rancangan acak lengkap dengan 4 perlakuan dan 4 ulangan dengan 10 ekor broiler setiap ulangan. Ransum perlakuan yang diberikan adalah: R1= Ransum mengandung $20 \%$ bungkil kedelai (BK) tanpa tepung pucuk I. zollingeriana (TPI); R2= Ransum mengandung $16 \%$ BK dan 5,9\% TPI (substitusi $20 \%$ protein BK oleh protein TPI); R3= Ransum mengandung $12 \%$ BK dan $11,8 \%$ TPI (substitusi $40 \%$ protein BK oleh protein TPI); R4= Ransum mengandung $8 \%$ BK dan $17,74 \%$ TPI (substitusi $60 \%$ protein BK oleh protein TPI). Peubah yang diamati adalah performa (konsumsi ransum, pertambahan bobot badan, dan konversi ransum) dan kualitas daging (kolesterol, kadar lemak, dan konsentrasi malondialdehid [MDA]) ayam broiler. Hasil penelitian menunjukkan bahwa penggunaan TPI sebanyak $17,74 \%$ sebagai substitusi $60 \%$ bungkil kedelai menghasilkan performa ayam broiler yang sama dengan pemberian ransum kontrol. Penggunaan $11,8 \%$ TPI sebagai substitusi $40 \%$ protein bungkil kedelai menurunkan kadar kolesterol daging sebanyak $34,70 \%$, kadar lemak daging $52,93 \%$, dan menurunkan MDA daging $62.52 \%$. Kesimpulan hasil penelitian adalah penggunaan $17,74 \%$ TPI dalam ransum ayam broiler menghasilkan performa yang sama dengan ransum kontrol dan dapat meningkatkan kandungan antioksidan yang ditandai dengan penurunan konsentrasi MDA, serta menurunkan kolesterol dan lemak pada daging ayam broiler.

Kata kunci: performa broiler, kolesterol, Indigofera zollingeriana, malondialdehid (MDA)

*Corresponding author:

E-mail: y sumiati@yahoo.com 


\section{INTRODUCTION}

The effort to meet the requirements of poultry's feed-protein source is still a major problem. Soybean meal has been used as a main source of plant protein for poultry diet, due to the fact that soybean meal contains about $48 \%$ protein (Leeson \& Summers, 2008). However, since soybean meal is mostly imported and the price is relatively expensive, the use of this feedstuff contributes to high cost of feed component. The utilization of other sources of protein for broiler chickens such as Jatropha curcas meal, soybean husk, and shrimp head waste to replace soybean meal has been carried out by Mirzah (2007), Mairizal (2009), and Sumiati et al. (2011). However, problems of unstable production, inconsistent quality, anti-nutrition contents, and high cost of processing technology are the main barriers of using this feedstuff. An alternative way that possible to be applied to overcome the problem is to use unconventional protein-rich feedstuff derived from the plant of legume group such as indigofera (Indigofera zollingeriana).

Indigofera, categorized as an unconventional feedstuff for poultry, has been reported to have numerous advantages for animal due to its rich content of certain nutrients. Some studies had reported that crude protein content of $I$. zollingeriana top leaf meal (ILM) ranged from 25.50\%-28.98\% (Hassen et al., 2007; Hassen et al., 2008; Akbarillah et al., 2008; Abdullah, 2010; Abdullah \& Suharlina, 2010; Tarigan et al., 2010; Palupi et al., 2014a). Considering its high nutritional content, especially protein, it is greatly possible that I. zollingeriana is potential to be used as a protein- contributing feedstuff for broiler chickens. In addition to its protein content, Indigofera leaf meal also contains high pigment such as xantofil and carotenoids (Akbarillah et al., 2010). Palupi et al. (2014a) reported that $\beta$-carotene of I. zollingeriana top leaf meal contains as much as $507.6 \mathrm{mg} / \mathrm{kg}$, and the usage of ILM in laying hens diet as much as $15.6 \%$ as a substitution of $45 \%$ protein of soybean meal increased egg production by $11 \%$, increased the antioxidant content by $59.17 \%$, as well as decreased cholesterol in egg yolks as much as $54.13 \%$.

Carotene content in Indigofera can be a good source of carotenoids for broiler chickens. Addition of dietary carotenoids source in broiler chickens is expected to produce meat containing high antioxidant and low cholesterol levels because $\beta$-carotene is one of antioxidants and functions as an important role in reducing free radical chain reaction on tissue. Accordingly, feeding this feedstuff to broiler chickens is expected to produce meat with high antioxidants and low in cholesterol levels because $\beta$-carotene is one of antioxidant function as an important role in reducing free radical chain reactions on tissue, and carotenoid content significantly inhibited lipid oxidation (Tavares et al., 2011; Kim et al., 2013). The level of cholesterol was decreased by feeding of carotenoids and $\beta$-carotene decreased the lipid peroxidation in skin, and the antioxidant activity of $\beta$-carotene was stronger (Lee et al., 2010). Carotenoids ( $\beta$-carotene) are important sources of antioxidant (Bertram \& Vine, 2005; Panovskai et al., 2005). The antioxidant activity of this plant was also reported in many publications (Kaur et al., 2006; Ordon et al., 2006; Alviano et al., 2008; Doddola et al., 2008).

The objective of this experiment was to study the effects of I. zollingeriana top leaf meal as substitution of soybean meal protein in the diet on cholesterol, fat content, and antioxidant concentration of broiler meat.

\section{MATERIALS AND METHODS}

The experiment was assigned in a completely randomized design (CRD) with four treatments and four replications with ten broiler chicken for each replication, and the birds were placed in cage of $1.5 \times 1.5 \mathrm{~m}$ in size. The experimental animals were 160 day-old Cobb chicks. The birds were fed dietary treatment when they were at day 15 (initial body weight was $450 \pm 1.56 \mathrm{~g} / \mathrm{bird}$ ) and terminated on day 35. Dietary treatments were: R1= diet containing 20\% SBM and without ILM (no substitution of SBM protein by ILM protein); R2= diet containing $16 \%$ SBM and 5.9\% ILM (substitution of $20 \%$ SBM protein by ILM protein); R3= diet containing 12\% SBM and $11.8 \%$ ILM (substitution of $40 \%$ SBM protein by ILM protein); R4= diet containing $8 \%$ SBM and $17.74 \%$ ILM (substitution of $60 \%$ SBM protein by ILM protein). The diets were formulated isocalori and isoprotein according to the recommendation of Leeson \& Summers (2008) (Table 1). Variables measured were feed consumption, body weight gain, feed conversion, and meat quality (cholesterol, fat content, and malondialdehyde concentration). Sixteen chickens were slaughtered by cervical dislocation. Muscles from right thigh part were isolated and mashed to analyze its cholesterol, fat, and MDA contents. Meat cholesterol content was measured according to Liebermann-Burchard method by using spectrophotometer (Hitachi U-2001, Japan) at $420 \mathrm{~nm}$ (Burke et al., 1974), meat fat content was assessed by using AOAC 2005 method, and malondialdehyde concentration was measured based on the method of Rice-Evans \& Anthony (1991).

\section{Statistical Analysis}

Data were subjected to analysis of variance (ANOVA) by using SPSS V21 IBM program, and the differences among treatment means were distinguished by Duncan's Multiple Range Test (Steel \& Torrie, 1995).

\section{RESULTS AND DISCUSSION}

\section{Treatment Effect on Broiler Chickens Performance}

Growth performances of broilers fed the experimental diets are presented in Table 2. Supplementation of I. zollingeriana top leaf meal in the diet of broiler chicken did not significantly affect feed consumption, body weight gain, and feed conversion. Supplementation of broiler diet with I. zollingeriana top leaf meal did not affect the feed palatability. It was indicated that $I$. zollingeriana top leaf meal could be given up to $17.74 \%$ for 2 to 5 -week broilers. The increased $\beta$-carotene content of diet supplemented with I. zollingeriana top leaf meal was able to increase endurance. Beta- 
Table 1. Composition and nutrient content of experimental diet of finisher period (2-5 weeks)

\begin{tabular}{|c|c|c|c|c|}
\hline Feed ingredients (\%) & R1 & $\mathrm{R} 2$ & R3 & $\mathrm{R} 4$ \\
\hline Corn & 60.00 & 59.50 & 58.70 & 57.33 \\
\hline Rice bran & 6.05 & 3.65 & 1.60 & 0.00 \\
\hline Corn gluten meal & 4.00 & 4.00 & 4.00 & 4.00 \\
\hline Soybean meal & 20.00 & 16.00 & 12.00 & 8.00 \\
\hline $\begin{array}{l}\text { Indigofera zollinge- } \\
\text { riana top leaf meal } \\
\text { (ILM) }\end{array}$ & 0.00 & 5.90 & 11.80 & 17.74 \\
\hline Fish meal & 5.75 & 6.40 & 7.00 & 7.60 \\
\hline Palm oil & 2.35 & 2.70 & 3.00 & 3.47 \\
\hline Dicalcium phosphate & 0.10 & 0.10 & 0.15 & 0.09 \\
\hline $\mathrm{CaCO}_{3}$ & 1.25 & 1.10 & 1.00 & 0.87 \\
\hline $\mathrm{NaCl}^{3}$ & 0.10 & 0.10 & 0.10 & 0.10 \\
\hline Premix & 0.30 & 0.30 & 0.30 & 0.30 \\
\hline L-Lysine & 0.00 & 0.10 & 0.20 & 0.30 \\
\hline DL-Methionine & 0.10 & 0.15 & 0.15 & 0.20 \\
\hline Total (\%) & 100.00 & 100.00 & 100.00 & 100.00 \\
\hline \multicolumn{5}{|c|}{ Nutrient content (calculated value / \%): } \\
\hline $\begin{array}{l}\text { Metabolizable energy } \\
(\mathrm{kcal} / \mathrm{kg})\end{array}$ & 3101.08 & 3105.45 & 3101.2 & 3101.13 \\
\hline Protein & 20.02 & 20.02 & 20.01 & 20.02 \\
\hline Ether extract & 5.25 & 5.52 & 5.74 & 6.13 \\
\hline Crude fiber & 2.98 & 3.36 & 3.78 & 4.23 \\
\hline Lysine & 1.13 & 1.13 & 1.12 & 1.11 \\
\hline Methionine & 0.55 & 0.58 & 0.55 & 0.57 \\
\hline Meth + cystine & 0.88 & 0.88 & 0.82 & 0.82 \\
\hline Calcium & 0.92 & 0.91 & 0.93 & 0.91 \\
\hline Phosphor & 0.45 & 0.46 & 0.47 & 0.46 \\
\hline Sodium & 0.12 & 0.11 & 0.11 & 0.11 \\
\hline Chloride & 0.14 & 0.14 & 0.14 & 0.14 \\
\hline
\end{tabular}

Note: R1= diet containing 20\% SBM without $I$. zollingeriana top leaf meal (ILM) (no substitution of SBM protein by ILM protein); R2= diet containing $16 \%$ SBM and $5.9 \%$ of ILM (substitution of 20\% SBM protein by ILM protein); R3= diet containing $12 \%$ SBM and $11.8 \%$ ILM (substitution of $40 \%$ SBM protein by ILM protein); R4= diet containing $8 \%$ SBM and $17.74 \%$ ILM (substitution of $60 \%$ SBM protein by ILM protein).

carotene has antioxidant activity that acts to improve the immune system. In addition, $\beta$-carotene serves as a barrier to free radicals, so the animal health can be improved and the feed consumption is maintained to support the optimum growth. Carotenoid supplementa- tion would improve immune condition (Cucco et al., 2007; Lee et al., 2010; Vrolijk et al., 2015). I. zollingeriana top leaf meal could be given to laying hens up to $15.6 \%$ as a substitution of $45 \%$ soybean meal protein without affecting feed consumption (Palupi et al., 2014b). Fresh leaves of Indigofera could be given in a diet of duck up to $10 \%$ without affecting the performance (Akbarillah et al., 2010).

Feeding I. zollingeriana top leaf meal as a feed supplementation did not affect body weight gain of broiler chicken (Table 2). The differences in body weight gain among the treatments were caused by the protein quality of I. zollingeriana top leaf meal that is similar to that of soybean meal. Proteins and amino acids that are sufficient in the diet will support optimal growth. The protein quality of I. zollingeriana top leaf meal is good, because the content of the Non Protein Nitrogen (NPN) is $1.12 \%$, and amino acid score of I. zollingeriana top leaf meal was 24.56 that is similar to amino acid content of soybean meal i.e., 26.50 (Palupi et al., 2014a). It was indicated that $I$. zollingeriana top leaf meal could be used in the diet of broiler chicken up to $17.74 \%$ as a substitution of $60 \%$ soybean meal protein. Soybean meal and I. zollingeriana top leaf meal did not have equivalent protein content, so substitution of soybean meal with $I$. zollingeriana top leaf meal was based on the proportion of soybean meal in the diet. Thus, soybean meal protein could be replaced by the protein of $I$. zollingeriana top leaf meal.

Supplementation of $I$. zollingeriana top leaf meal at the levels of $5.9 \%, 11.8 \%$, and $17.74 \%$ in the diet as substitutions of $20 \%, 40 \%$, and $60 \%$ soybean meal protein, respectively, did not affect feed conversion ratio, compared with control diet (Table 2). Beta-carotene in the I. zollingeriana top leaf meal can maintain the health of broiler chickens and feed intake can be maintained to achieve the optimum weight gain. Beta-carotene could maintain rat growth (Siqueira et al., 2007). Therefore, incorporation of dietary antioxidants in poultry feed had been implemented to achieve optimal growth performance, reproduction, and meat quality (Li et al., 2009; Delles et al., 2014). This good effect could be related to the amino acid contents of I. zollingeriana top leaf meal that could replace amino acid of soybean meal. The similarity of feed conversion ratio obtained in this study was due to the fact that feed consumption and body weight gain were also similar in all treatments.

Table 2. Feed consumption, body weight gain, and feed conversion of broiler chicken during treatments (2-5 weeks)

\begin{tabular}{|c|c|c|c|c|}
\hline \multirow{2}{*}{ Variables } & \multicolumn{4}{|c|}{ Treatments } \\
\hline & R1 & $\mathrm{R} 2$ & $\mathrm{R} 3$ & $\mathrm{R} 4$ \\
\hline Feed consumption (g/bird) & $2043.66 \pm 108.64$ & $2135.29 \pm 64.62$ & $2147.67 \pm 63.08$ & $2216.81 \pm 76.12$ \\
\hline Final body weight (g/bird) & $1379.50 \pm 86.60$ & $1383.61 \pm 68.17$ & $1382.50 \pm 72.14$ & $1382.83 \pm 45.54$ \\
\hline Body weight gain (g/bird) & $917.50 \pm 86.89$ & $923.61 \pm 68.17$ & $922.50 \pm 72.14$ & $922.83 \pm 45.82$ \\
\hline Feed conversion ratio (FCR) & $2.25 \pm 0.28$ & $2.32 \pm 0.20$ & $2.34 \pm 0.20$ & $2.40 \pm 0.10$ \\
\hline
\end{tabular}

Note: R1= diet containing 20\% SBM without I. zollingeriana top leaf meal (ILM) (no substitution of SBM protein by ILM protein); R2= diet containing $16 \%$ SBM and $5.9 \%$ of ILM (substitution of $20 \%$ SBM protein by ILM protein); R3= diet containing $12 \%$ SBM and $11.8 \%$ ILM (substitution of $40 \%$ SBM protein by ILM protein); R4= diet containing $8 \%$ SBM and $17.74 \%$ ILM (substitution of $60 \%$ SBM protein by ILM protein). 


\section{Meat Quality of Broiler Chicken}

The averages of cholesterol, fat content, and malondialdehyde concentrations of broiler-chicken meat are presented in Table 3. Substitution of soybeanmeal protein with $I$. zollingeriana top leaf meal protein significantly $(\mathrm{P}<0.05)$ decreased meat cholesterol and fat content, compared with R1. Supplementation of I. zollingeriana top leaf meal at the levels of $11.8 \%$ (R3) and $17.74 \%$ (R4) into the diet significantly decreased malondialdehyde concentration as compared with R1 and R2. Supplementation of $11.8 \%$ I. zollingeriana top leaf meal as a substitution of $40 \%$ soybean meal protein reduced meat cholesterol by $34.70 \%$ (158.31 \pm 17.08 $\mathrm{mg} / 100 \mathrm{~g}$ to $103.38 \pm 25.80 \mathrm{mg} / 100 \mathrm{~g})$, meat fat content by $52.92 \%(9.31 \pm 0.65 \%$ to $4.38 \pm 1.18 \%)$, and meat MDA concentration by $62.52 \%(7.13 \pm 0.66 \mu \mathrm{g} / \mathrm{g}$ to $2.67 \pm 0.62 \mu \mathrm{g} / \mathrm{g})$. The present result was in accordance with the report of Palupi et al. (2014b) that feeding of $15.6 \%$ I. zollingeriana top leaf meal as a substitution of $45 \%$ soybean meal protein in laying hens decreased cholesterol content by $54.13 \%$ and increased egg antioxidant content up to $59.17 \%$.

The decreased of meat cholesterol and fat content was caused by $\beta$-carotene content of $I$. zoolingeriana. Cholesterol biosynthesis from acetyl CoA requires the presence of HMG-CoA reductase (hydroximetyl glutaryl-CoA) enzyme to form mevalonate. The activity of the HMG-CoA reductase will be disturbed by $\beta$-carotene contained in I. zollingeriana top leaf meal. Beta carotene content of I. zollingeriana top leaf meal was $506.7 \mathrm{mg} / \mathrm{kg}$ (Palupi et al., 2014a). Carotenoid ( $\beta$-carotene) contained in I. zollingeriana top leaf meal has an effect to reduce cholesterol in blood serum through inhibiting micelle formation in small intestine so that decreases intestinal cholesterol absorption. Carotenoids are antioxidants that can prevent oxidation of lipids, and carotenoids are able to inhibit the action of the enzyme activity of HMG Co-A reductase to form mevalonate that is required for the synthesis of cholesterol (Eisenbrand, 2005). The high content of $\beta$-carotene in feedstuffs consumed decreases cholesterol content of carcass (Lee et al., 2010; Syahruddin et al., 2011). Reduced levels of cholesterol resulted in the decreased transport of cholesterol to tissues so that the fat content of meat is reduced. Considering that $\beta$-carotene could inhibit enzyme HMG-CoA in the formation of cholesterol, this compound could reduce the amount of fat attached to the arterial wall. Decreased amount of fat in the arteries caused the reduced fat transport to the meat (Fki et al., 2005).

Beta-carotene is an active compound that lowers blood lipid and $\beta$-carotene could reduce MDA concentration in broiler meat. Lower cholesterol and fat content resulted in lower lipid peroxidation, so the meat MDA levels also decreased. The lower meat MDA concentration indicated that meat of broiler chicken contains high antioxidant. The higher level of I. zollingeriana top leaf meal supplementation in broiler chicken diet would further increase deposition of $\beta$-carotene in the meat. This was due to an increase in absorption of $\beta$-carotene derived from I. zollingeriana top leaf meal. Xantophyll and $\beta$-carotene are the sources of antioxidant that could increase the yolk pigmentation and improve the health of chicken (Lee et al., 2010). Beta-carotene is a natural antioxidant that can protect the cellular component from the biological damage caused by Reactive Oxygen Species (ROS). High concentrations of antioxidants have been demonstrated to reduce lipid peroxidation in chicken's muscle (Jiang et al., 2007).

Malondialdehyde is one of the most frequently used indicators of lipid peroxidation associated with oxidative stress (Aksu et al., 2010). Lipid oxidation is one of the main factors limiting the quality and acceptability of meats and meat products (Jiang et al., 2007). Free radical and lipid peroxidation have been implicated in the deterioration of many physiological functions including growth, reproduction, and immunity (Gladine et al., 2007). The decreased meat MDA concentration could be due to the ability of $\beta$-carotene to affect antioxidant defense system. In the present study, the meat MDA concentration showed a significant decrease with the supplementation of $11.8 \%$ and $17.74 \%$ ILM in the diets. The mechanism of beta-carotene to counteract with free radicals is occurred via electron (Dutta et al., 2005). Antioxidant supplementation improved breast quality of broiler chicken (Tavarez et al., 2011). Dietary antioxidants improved meat tenderness and reduced lipid oxidation in broiler breast and thigh meat (Delles et al., 2014).

\section{CONCLUSION}

Feeding $17.74 \%$ ILM as the substitution of $60 \%$ soybean meal protein in broiler produced the same performances as that of control diet, but reduced the MDA concentration, cholesterol, and fat content of broilerchicken meat.

Table 3. Cholesterol and fat contents, and malondialdehyde (MDA) concentration of broiler-chicken meat

\begin{tabular}{|c|c|c|c|c|}
\hline \multirow{2}{*}{ Variables } & \multicolumn{4}{|c|}{ Treatments } \\
\hline & R1 & $\mathrm{R} 2$ & $\mathrm{R} 3$ & $\mathrm{R} 4$ \\
\hline Cholesterol (mg/100g) & $158.31 \pm 17.08^{\mathrm{a}}$ & $106.92 \pm 19.38^{b}$ & $103.38 \pm 25.80^{b}$ & $111.61 \pm 20.52^{b}$ \\
\hline Fat $(\%)$ & $9.31 \pm 0.65^{\mathrm{a}}$ & $6.01 \pm 1.05^{\mathrm{b}}$ & $4.38 \pm 1.18^{\mathrm{c}}$ & $4.53 \pm 0.93^{\mathrm{bc}}$ \\
\hline Malondialdehyde $(\mu \mathrm{g} / \mathrm{g})$ & $7.13 \pm 0.66^{\mathrm{a}}$ & $6.95 \pm 0.64^{\mathrm{a}}$ & $2.67 \pm 0.62^{b}$ & $4.56 \pm 0.60^{c}$ \\
\hline
\end{tabular}

Note: Means in the same row with different superscripts differ significantly $(\mathrm{P}<0.05)$. R1= diet containing $20 \%$ SBM without $I$. zollingeriana top leaf meal (ILM) (no substitution of SBM protein by ILM protein); R2= diet containing $16 \%$ SBM and 5.9\% of ILM (substitution of $20 \%$ SBM protein by ILM protein); R3= diet containing 12\% SBM and 11.8\% ILM (substitution of 40\% SBM protein by ILM protein); R4= diet containing $8 \%$ SBM and 17.74\% ILM (substitution of $60 \%$ SBM protein by ILM protein). 


\section{REFERENCES}

Abdullah, L. 2010. Herbage production and quality of shrub indigofera treated by different concentration of foliar fertilizer. Med. Pet. 33: 169-175. http://dx.doi.org/10.5398/medpet.2010.33.3.169

Ahdullah., L. \& Suharlina. 2010. Herbage yeld and quality of two vegetative parts of Indigofera at different times of first regrowth defoliation. Med. Pet. 33: 44-49.

Akbarillah, T., Kususiyah, \& Hidayat. 2010. Pengaruh penggunaan daun indigofera segar sebagai suplemen pakan terhadap produksi dan warna yolk itik. JSPI. 5: 27-33.

Akbarillah, T., Kususiyah, D. Kaharuddin, \& Hidayat. 2008. Kajian tepung daun indigofera sebagai suplemen pakan terhadap produksi dan kualitas telur puyuh. JSPI. 3: 20-23.

Aksu, D. S., T. Aksu, B. Ozsoy, \& E. Baytok. 2010. The effects of replacing inorganic with a lower level of organically complexed minerals ( $\mathrm{Cu}, \mathrm{Zn}$ and $\mathrm{Mn}$ ) in broiler diets on lipid peroxidation and antioxidant defense systems. AsianAust. J. Anim. Sci. 23:1066-1072. http://dx.doi.org/10.5713/ ajas.2010.90534

Alviano, W. S., D. S. Alviano, C. G. Diniz, A. R. Antoniolli, C. S. Alviano, L. M. Farias, M. A. R. Carvalho, M. M. G. Souza, \& A. M. Bolognese. 2008. In vitro antioxidant potential of medicinal plant extracts and their activities against oral bacteria based on Brazilian folk medicine. Arch. Oral Biol. 53: 545-552. http://dx.doi.org/10.1016/j.archoralbio.2007.12.001

AOAC. 2005. Official Methods of Analysis of AOAC International. 18th ed. Assoc. Off. Anal. Chem. Arlington.

Bertram, J. S. \& A. L. Vine. 2005. Cancer prevention by retinoids and carotenoids: independent action on a common target. Biochem. Biophys. Acta. 1740: 170-178. http://dx.doi. org/10.1016/j.bbadis.2005.01.003

Burke, R. W., B. I. Diamondstone, R. A. Velapoldi, \& O. Menis. 1974. Mechanisms of the Liebermann- Burchard and Zak Color Reactions for Cholesterol. Clin. Chem. 20: 794-801.

Cucco, M., B. Guasco, G. Malarne, \& R. Ottonelli. 2007. Effects of $\beta$-carotene supplementation on chick growth, immune status and behaviour in the grey partridge, Perdix perdix. Behavioural Processes. 73: 325-332.

Delles, R. M., Y. L. Xiong, A. D. Treu, T. Ao, \& K. A. Dawson. 2014. Dietary antioxidant supplementation enhances lipid and protein oxidative stability of chicken broiler meat through promotion of antioxidant enzyme activity. Poult. Sci. 93: 1561-1570. http://dx.doi.org/10.3382/ps.2013-03682

Doddola, S., H. Pasupulati, B. Kogantia, \& K. V. S. G. Prasad. 2008. Evaluation of sesbania grandifora for antiurolithiatic and antioxidant properties. J. Nat. Med. (Tokyo) 62: 300307. http://dx.doi.org/10.1007/s11418-008-0235-2

Dutta, D, U. R. Chaudhuri, \& R. Chakraborty. 2005. Sructure, health benefits. Antioxidant property and processing and storage of carotenoids. African J of Biotech. 4: 1510-1520.

Eisenbrand, G. 2005. Toxicological Evaluation of Red Mould Rice. Mol. Nutr. Food Res. 50: 322-327. http://dx.doi. org/10.1002/mnfr.200690011

Fki, I., M. Bouaziz, Z. Sahnoun, \& S. Sayadi. 2005. Hypocholesterolemic effects of phenolic-rich extracts of chemlali olive cultivar in rat fed a cholesterol-rich diet. J. Bioorg. Med. Chem. 13: 5362-5370. http://dx.doi.org/10.1016/j. bmc.2005.05.036

Gladine, C., C. Morand, E. Rock, D. Gruffat, D. Bauchart, \& D. Durand. 2007. The antioxidative effect of plant extracts rich in polyphenols differs between liver and muscle tissues in rats fed n-3 PUFA rich diet. Anim. Feed Sci. Technol. 139:257-272. http://dx.doi.org/10.1016/j.anifeedsci.2007.01.015

Hassen, A., N. F. G. Rethman, W. A. Van Niekerk, \& T. J. Tjelele. 2007. Influence of season/year and species on chemical composition and in vitro digestibility of five indigofera accession. Anim. Feed Sci. Technol. 136: 312-322. http:// dx.doi.org/10.1016/j.anifeedsci.2006.09.010

Hassen, A., N. F. G. Rethman, Z. Apostolides, \& W. A Van Niekerk. 2008. Forage production and potential nutritive value of 24 shubby Indigofera accession under field conditions in South Africa. Trop Grassland. 42: 96-103.

Jiang, S. Q., Z. Y. Jiang, Y. C. Lin, P. B. Xi, \& X. Y. Ma. 2007. Effect of soy isoflavone on performance, meat quality and antioxidative property of male broilers fed oxidazed fish oil. Asian-Aust. J. Anim. Sci. 20: 1252-1257.

Kaur, G., M. S. Alam, Z. Jabbar, K. Javed, \& M. Athar. 2006. Evaluation of antioxidant activity of Cassia siamea flowers. J. Ethnopharmacol. 108: 340-348. http://dx.doi. org/10.1016/j.jep.2006.05.021

Kim, I. S., S. K. Jin, M. R. Yang, G. M. Chu, J. H. Park, R. H. I. Rashid, J. Y. Kim, \& S. N. Kang. 2013. Efficacy of tomato powder as antioxidant in cooked pork patties. Asian-Aust. J. Anim. Sci. 26: 1339-1346.

Lee, C.X., B. D. Lee, J-C. Na, \& G. An. 2010. Carotenoid accumulation and their antioxidant activity in spent laying hens as affected by polarity and feeding period. AsianAust. J. Anim. Sci. 23: 799-805.

Leeson, S. \& J. D. Summers. 2008. Commercial Poultry Nutrition. 3rd Ed. Departement of Animal and Poultry Science, University Guelph.University Books, Guelph.

Li, W. J., G. P. Zhao, J. L. Chen, M. Q. Zheng, \& J. Wen. 2009. Influence of dietary vitamin E supplementation on meat quality traits and gene expression related to lipid metabolism in the Beijing-you chicken. Br. Poult. Sci. 50: 188-198. http://dx.doi.org/10.1080/00071660902755409

Mairizal. 2009. Pengaruh pemberian kulit ari biji kedelai hasil fermentasi dengan aspergilus niger sebagai pengganti jagung dan bungkil kedelai dalam ransum terhadap retensi bahan kering, bahan organik dan serat kasar pada ayam pedaging. Jurnal Ilmiah Ilmu Peternakan. 10: 35-40.

Mirzah. 2007. Penggunaan tepung limbah udang yang diolah dengan filtrat air abu sekam dalam ransum ayam broiler. Med. Pet. 30: 189-197.

Ordon, Ez. A. A. L., J. D. Gomes, M. A. Vattuone, \& M. I. Isla. 2006. Antioxidant activities of Sechium edule (Jacq) swart extracts. Food Chem. 97: 452-458. http://dx.doi.org/10.1016/j. foodchem.2005.05.024

Palupi, R., L. Abdullah , D. A. Astuti, \& Sumiati. 2014a. Potensi dan pemanfaatan tepung pucuk Indigofera sp. sebagai bahan pakan substitusi bungkil kedelai dalam ransum ayam petelur. JITV. 19:210-219.

Palupi, R., L. Abdullah, D. A. Astuti, \& Sumiati. 2014b. High antioxidant egg production through subsitution of soybean meal by Indigofera sp top leaf meal in laying hen diets. Int. J. Poult. Sci. 13: 198-203. http://dx.doi.org/10.3923/ ijps.2014.198.203

Panovskai, T. K., S. Kulevanova, \& M. Stefova. 2005. In vitro antioxidant activity of some Teucrium species Lamiaceae). Acta Pharm. 55: 207-214.

Rice-Evans, C. \& T. D. Anthony. 1991. Techniques in free radical research. Elsevier. Pp: 146-202.

Siqueira, E. M. A., S. F. Arruda, R. M. Vargass, \& E. M. T. Souza. 2007. $\beta$-Carotene from cassava (Manihot esculenta Crantz) leaves improves vitamin A status in rats. Comp. Biochem. Phys. C. 146: 235-240. http://dx.doi.org/10.1016/j. cbpc.2006.12.006

Steel, R. G. D. \& J. H. Torrie. 1995. Prinsip dan Prosedur Statistika. Terjemahan: B. Sumantri. Gramedia, Jakarta.

Sumiati., Farhanuddin, W. Hermana, A. Sudarman, N. Istichomah, \& A. Setiyono. 2011. Performa ayam broiler yang diberi ransum mengandung bungkil biji jarak pagar (Jatropha curcas L) hasil fermentasi menggunakan Rhizophus oligosporus. Med. Pet. 34: 117-125. http://dx.doi.org/10.5398/ 
medpet.2011.34.2.117

Syahruddin, E., H. Abbas, E. Purwati, \& Y. Heryandi. 2011. Effect of fermented noni leaf (Morinda Citrifolia L.) in diets on cholesterol content of broiler chicken carcass. JITV. 16: 266-271.

Tarigan, A., L. Abdullah., S. P. Ginting, \& I. G. Permana. 2010. Produksi dan komposisi serta nutrisi in vitro Indigofera sp. pada interval dan tinggi pemotongan berbeda. JITV. 15: 188-195.
Tavarez, M. A., D. D. Boler., K. N. Bess., J. Zhao., F. Yan., A. C. Dilger., F. K. McKeith, \& J. Killefer. 2011. Effect of antioxidant and oil quality on broiler performance, meat quality and lipid oxidation. Poult. Sci. 90: 922-930. http://dx.doi. org/10.3382/ps.2010-01180

Vrolijk, M. F., A. Opperhuizen, E. H. J. M. Jansen, R. W. Godschalk, F. J. V. Schooten, A. Bast, G. R. M. M. Haenen. 2015. The shifting perception on antioxidants: The case of vitamin E and $\beta$-carotene. Redox Biology. 4: 272-278. http://dx.doi.org/10.1016/j.redox.2014.12.017 